\title{
Stable carbon isotope analyses offer insights into net carbon degradation of maize silages in anaerobic batch fermentations
}

\author{
Daniel Einfalt $^{1,2}(\mathbb{D}) \cdot$ Martin Werth $^{1} \cdot$ Daniel Schropp $^{1,3} \cdot$ Marian Kazda $^{1}$
}

Received: 23 July 2019 / Accepted: 22 December 2019 / Published online: 16 January 2020

(C) The Author(s) 2020

\begin{abstract}
Carbon degradation indicates the efficiency of anaerobic digestion processes. Common carbon degradation determination methods define gross carbon degradation ( $\mathrm{C}$ deg gross $)$ of substrate and inoculum inseparably. The aim of this study was to test an isotope-based method defining solely substrate-based net carbon degradation $\left(\mathrm{C} \operatorname{deg}_{\text {net }}\right)$ on maize silage. As the natural abundance of stable isotopes in agricultural substrates vary, the method's applicability was tested on (i) different maize silages sampled from agricultural farms, (ii) maize silage in fresh $\left(\mathrm{MS}_{\text {fresh }}\right)$ and impaired storage $\left(\mathrm{MS}_{\text {impaired }}\right)$ conditions. Experiments included six maize silages digested in a total of 19 lab-scale batch reactors, analyzed for digestion parameters, stable isotopes, gross and net carbon degradation. $\mathrm{MS}_{\text {impaired }}$ showed significantly different stable carbon isotope composition at the start of the experiments, compared to $\mathrm{MS}_{\text {fresh }}$. Both methods indicated quality losses in $\mathrm{MS}_{\text {impaired. }}$ Results showed significantly higher $\mathrm{C}$ $\operatorname{deg}_{\text {net }}$ values, ranging from $58.4 \%$ to $86.5 \%$, compared to deg gross values, ranging from $23.1 \%$ to $48.7 \%$. This indicated the applicability of an isotope-based method $\mathrm{C} \operatorname{deg}_{\text {net }}$ to assess net carbon degradation of maize silages more detailed by excluding the masking effect of the inoculum. The isotope-based net carbon degradation method was found applicable on maize silages from (i) different farms and (ii) in different storage qualities.
\end{abstract}

Keywords $\delta^{13} \mathrm{C} \cdot$ Biogas $\cdot$ Net carbon degradation $\cdot$ Maize silage $\cdot$ Stable isotopes

\begin{abstract}
Abbreviations
$\mathrm{C} \operatorname{deg}_{\text {gross }}$

gross carbon degradation determination method of reactor mixture

$\mathrm{C} \operatorname{deg}_{\mathrm{MS}}$ net carbon degradation determination approach based on control reactor

C deg

$\mathrm{C}$ mass $_{\mathrm{MS}}$ net carbon degradation determination method using stable isotopes
\end{abstract}

Daniel Einfalt

daniel.einfalt@uni-hohenheim.de

Institute of Systematic Botany and Ecology, Ulm University, Albert-Einstein-Allee 11, 89081 Ulm, Germany

2 Present address: Institute of Food Science and Biotechnology, Yeast Genetics and Fermentation Technology, University of Hohenheim, Garbenstraße 23, 70599 Stuttgart, Germany

3 Present address: Institute of Psychology and Education, Dept. Learning and Instruction, Ulm University, Albert-Einstein-Allee 47, 89081 Ulm, Germany
Maize silage carbon mass analysed by carbon mass balance

$\mathrm{C}$ mass Inoc $_{\text {Inoculum carbon mass analysed }}$ by carbon mass balance

$\mathrm{C}$ mass $f_{\mathrm{MS}} \quad$ Carbon mass analysed by stable isotope fraction

$\mathrm{MS}_{\text {fresh }} \quad$ fresh maize silage

$\mathrm{MS}_{\text {impaired }}$ maize silage with impaired storage

\section{Introduction}

Maize silage is one of the most important substrates in German biogas production (FNR 2017). An efficient transformation of substrate-bound carbon $(\mathrm{C})$ to biogas during the anaerobic digestion process is one key aim for biogas plant operators. Therefore, many scientifically conducted experiments in lab-scale biogas reactors focused on maize silage degradations in order to analyze degradation efficiency. Commonly, degradation determination methods are based on volatile solids (VS), which serve as basis for specific biogas 
yield calculations. More detailed information on carbon degradation is gained by carbon mass quantification at start and end of the experiment. The carbon masses are used to determine gross carbon degradation of the substrate in anaerobic digestions ( $\mathrm{C}$ deg $_{\text {gross }}$ ) (Bisutti et al. 2004). Anaerobic digestion experiments are often performed in batch processes which, in the simplest case, are set up with one inoculum and one substrate (e.g. maize silage). Gross carbon degradation determination methods, however, offer no possibility to identify solely substrate-bound carbon degradation without taking carbon of the applied inoculum into account. Often indirect approaches are presented by analyzing carbon degradation in separately digested inoculum (control). Interactions between inocula and substrates are, however, neglected. To achieve a better understanding of the net degradation process, it is required to gain additional information about substrate degradation independently of the contributing inoculum.

Environmental and geosciences have intensively used natural abundance of stable isotopes to investigate diverse physical, chemical and biological processes in oxic (Bowling et al. 2008; Brüggemann et al. 2011; Werth and Kuzyakov 2010) and anoxic (Conrad 2005) environments. Most biochemical processes favour the incorporation of the lighter isotope $\left({ }^{12} \mathrm{C}\right)$ in the product. This leads to differences between the isotopic composition of the substrate and the product. In biological systems, such isotope fractionation is also defined as discrimination, because specific enzymatic reactions discriminate against the heavier $\left({ }^{13} \mathrm{C}\right)$ and favour the lighter isotope. Natural variations of ${ }^{13} \mathrm{C} /{ }^{12} \mathrm{C}$ ratios have been used to trace $\mathrm{C}$ sources and fluxes in biological systems. The $\mathrm{C}$ isotope ratios are expressed relative to international standard as $\delta^{13} \mathrm{C}$ or $\delta^{15} \mathrm{~N}$, for nitrogen based research, values. Many studies are based on the natural variation of $\delta^{13} \mathrm{C}_{\text {in }} \mathrm{C}_{3}$ and $\mathrm{C}_{4}$ vegetation. The $\delta^{13} \mathrm{C}$ values of $\mathrm{C}_{3}$ and $\mathrm{C}_{4}$ plants range from -10 to -28 $\% o$ and from -9 to $-17 \%$, respectively (Werth and Kuzyakov 2010). Maize is highly enriched in the heavier ${ }^{13} \mathrm{C}$ isotope as a consequence of the $\mathrm{C}_{4}$ metabolic pathway in photosynthesis compared to $\mathrm{C}_{3}$ plants (Smith and Epstein 1971). This difference in natural ${ }^{13} \mathrm{C}$ abundance has been exploited to study carbon turnovers (Amelung et al. 2008). In anaerobic processes, stable isotopes have been successfully used to identify microbiological reaction pathways (e.g. Conrad 2005; Francioso et al. 2010; Gehring et al. 2015; Gelwicks et al. 1994; Penger et al. 2014). Most studies either used in-vitro methods of specific microorganisms, municipal wastewater treatment plants, or concentrated exclusively on exhausted gasses. For instance, anaerobic $\mathrm{CH}_{4}$ production is known for a strong ${ }^{13} \mathrm{C}$ fractionation factor (typically $10-70$ $\%$ o) which simultaneously affects $\delta^{13} \mathrm{C}$ values in the product (Conrad et al. 2012). Investigations into agricultural biogas reactor contents and substrates are, however, rare.

Our study focused on the implementation of a simple isotope-based method to identify maize silage-bound net carbon degradation $\left(\mathrm{C}\right.$ deg $\left._{\text {net }}\right)$ in agricultural biogas plant inoculum. Maize silages cultivated under organic farming standards occur frequently as biogas substrates (Einfalt and Kazda 2016). However, so far maize silages cultivated according to organic farming standards, have not been qualitatively investigated regarding anaerobic digestion performance. This manuscript provides additional information on this aspect.

The main aim was to test the applicability of net carbon degradation assessment by stable carbon isotope analysis (C $\left.\mathrm{deg}_{\text {net }}\right)$. As biological processes continuously affect the natural variation of $\delta^{13} \mathrm{C}$ values in silages, the applicability of $\mathrm{C}$ deg net $_{\text {na }}$ determination was tested on (i) maize silages from different agricultural farms in (ii) fresh $\left(\mathrm{MS}_{\text {fresh }}\right)$ and impaired storage

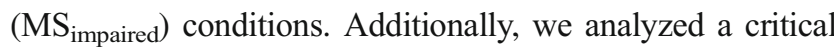
setup with (iii) mixed $\mathrm{C}_{3}$ and $\mathrm{C}_{4}$ substrate pools. The hypothesis tested differences on applied gross and net carbon degradation determination methods, which were expected between experiments with $\mathrm{MS}_{\text {fresh }}$ and $\mathrm{MS}_{\text {impaired. Additional analyses }}$ of digestion parameters of different maize silages offered the possibility to identify possible inhibition processes within the experiments. For validation of the $\mathrm{C}$ deg net $_{\text {values, the results }}$ were compared to specific biogas yields (sby) and specific methane yields (smy) from separately conducted experiments.

\section{Material and methods}

\section{Substrates}

All samples were collected from farms equipped with biogas plants in the southern part of Germany. Inocula Inoc1 and Inoc2 originated from an organic farm with a biogas plant operating at $38{ }^{\circ} \mathrm{C}$. Feedstock consisted of cattle manure, cattle dung and clover silage (52.8\% fresh weight (FW) of total feedstock). For more detailed information, see biogas plant No. 11 in Einfalt and Kazda (2016). The inocula were sampled individually in September (Inoc1) and October (Inoc2) 2012 and stored under anaerobic conditions at $38{ }^{\circ} \mathrm{C}$ for 4 days. Samples were extracted at the outflow of the main reactor. Additionally conducted experiments with inoculum extracted in May 2014 from the same biogas plant showed a residual biogas potential of $15.5 \mathrm{~L} \mathrm{~kg}^{-1} \mathrm{~d}^{-1}$. Inoculum Inoc3 was extracted from a mesophilic $\left(40^{\circ} \mathrm{C}\right)$ biogas plant in April 2014, utilizing cattle manure, cattle dung, maize silage $(50.0 \% \mathrm{FW}$ of total feedstock) and grass silage (16.7\% FW of total feedstock). The inoculum Inoc3 was stored in the reactors of experiment $\mathrm{E} 3$ for 11 days at $42{ }^{\circ} \mathrm{C}$ for microbial adaptation and reduction of background biogas production by the inoculum. It showed an average of $13.7 \mathrm{~L} \mathrm{~kg}^{-1} \mathrm{~d}^{-1}$ residual biogas production prior to the start of the experiment.

Maize (Zea mays L.) silage sampling was conducted according to VDLUFA (1997). Maize silage MS1 and MS2 were sampled on two conventional farms situated in 
Seligweiler (German postal zip code (PZC) 89,081) and Unterweiler (PZC 89079), respectively. MS3 and MS4 were sampled on organic farms situated in Mettenberg (PZC 88440) and Niederstetten (PZC 97996), respectively. All samples were collected in June and July 2012. MS5 and MS6 were sampled separately in April 2014 from similar farms in Unterweiler and Mettenberg. According to the farmer, organic maize silage MS6 was ensiled with sunflower plants (ca. 5\% FW). Until start of experiments, all maize silages were stored in sealed plastic bags at $6{ }^{\circ} \mathrm{C}$.

\section{Experimental setup}

The experiments were conducted in three anaerobic batch digestion experiments. The first experiment (E1) was performed with nine one-liter glass flask reactors located in a closed PVC box and heated continuously to $38 \pm 0.5^{\circ} \mathrm{C}$. Every flask had a gastight sealing including a biogas outlet and a dip tube, reaching below liquid surface, for sample extraction (Fig. 1). Exhausted biogas was led through flexible tubes into a waterfilled glass to prevent reverse aeration before being diverted to discharged air. All reactors were continuously stirred on a platform shaker (110 rpm). They contained $700 \mathrm{~mL}$ inoculum (Inoc1) and MS1 to MS4. Experiment E1 focused on $\mathrm{MS}_{\text {fresh }}$. Every maize silage was digested in two reactors as duplicates. One control reactor contained only inoculum Inoc1. The second experiment (E2) had a similar setup with a new sampled inoculum (Inoc2, $700 \mathrm{~mL}$ ) and the same maize silages MS1 to MS4 digested in duplicates. Prior to the start of experiment E2, subsamples (ca. $3.0 \mathrm{~kg}$ ) of maize silages MS1 to MS4 from experiment $\mathrm{E} 1$ were kept for 47 days at $21 \pm 1.0^{\circ} \mathrm{C}$ while stored in gastight plastic bags to simulate poor storage conditions. Therefore, the maize silages of experiment E2 are referred to as maize silages with impaired storage qualities

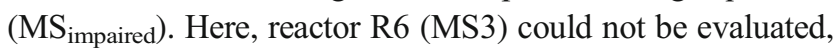
due to technical problems. One control reactor contained exclusively inoculum Inoc2. Each reactor in experiments E1 and E2 was filled with up to $150 \mathrm{~mL}$ of water to achieve consistent total volume of $900 \mathrm{~mL}$. In this study, reactor contents are referred to as mixtures (mix) of maize and inocula. The

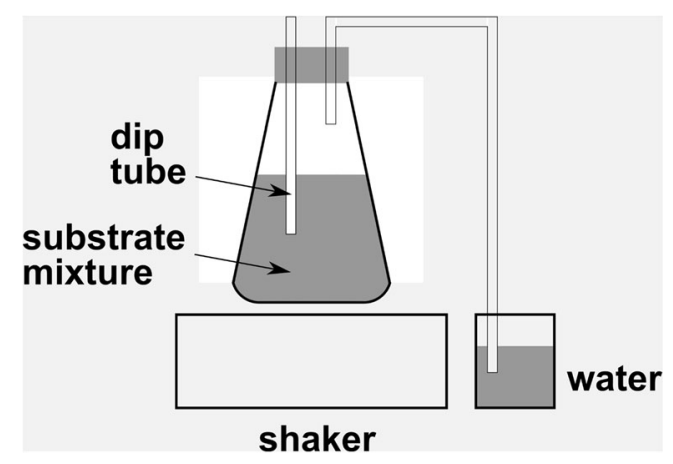

Fig. 1 Schematic reactor setup organic loadings (OL; based on VS) of the reactors at start of experiments E1 and E2 were $13.3 \pm 1.1 \mathrm{~kg} \mathrm{~m}^{-3}$ and 13.9 $\pm 0.0 \mathrm{~kg} \mathrm{~m}^{-3}$, respectively. The duration of both experiments was 29 days. In E1, $7 \mathrm{~mL}$ of reactor samples were extracted via dip tube at day $1,4,6,8,11,13,15,18,22$ and 29 for analysis of digestion parameters.

A third experiment (E3) was carried out with four 121 labscale batch reactors. A water bath was used to maintain the temperature of the digesters at $42 \pm 0.5{ }^{\circ} \mathrm{C}$. Reactors were mixed (40 rpm) every 15 min with installed paddle mixers. Maize silages MS5 and MS6 were digested in duplicates with inoculum Inoc3 (9.0 1). Each reactor was water-filled to a volume of 9.6 L. For analysis of digestion parameters, $7 \mathrm{~mL}$ samples were extracted via dip tube at day $1,2,7,10,14,16$, 21 and 29. Produced biogas was analyzed for volumes and methane concentrations and evaluated for specific biogas (sby) and methane yield (smy). A fifth reactor (1 1 glass flask) with reverse aeration protection was added to the water bath and operated as a control containing exclusively inoculum Inoc3. The OL was set to $15.0 \mathrm{~kg} \mathrm{~m}^{-3}$ for an experimental duration of 64 days.

\section{Sample analysis and evaluation}

All inocula, maize silages and reactor mixtures at start and end of the experiments were analyzed for total solids (TS), VS and pH (excluding MS1 to MS4) according to standard methods ASTM E1756-08(2015), ASTM E1755-01(2015) and ASTM E70-07(2015), respectively. Total $\mathrm{C}$ and nitrogen (N) concentrations were analyzed in dried $\left(60^{\circ} \mathrm{C}\right)$ and ground (particle size $<0.5 \mathrm{~mm}$ ) samples with an elemental analyzer (LECO TrueSpec CN, LECO, St. Joseph, USA). Inocula were tested for VFA total alkaline capacity (TAC) buffer stability (VFA/TAC) (Voß et al. 2009) (Table 1).

In experiment E1, three major parameters were analyzed, including digestion parameters, stable isotope composition and carbon degradation. Experiment E2 focused on stable isotope compositions and carbon degradations. Data from reactors containing $\mathrm{MS}_{\text {fresh }}$ (experiment E1) and $\mathrm{MS}_{\text {impaired }}$ (experiment E2) were compared to elucidate differences between maize silages of fresh and impaired storage qualities. Experiment E3 was analyzed for differences in digestion parameters, sby, smy, stable isotope compositions and carbon degradations.

Digestion parameters included pH, VFA/TAC, acetic, propionic and butyric acid concentrations, which were analyzed consecutively in experiments E1 and E3. Organic acid analysis was performed on subsamples of the extracted reactor contents. Subsamples were immediately diluted to $50 \%(\mathrm{v} / \mathrm{v})$ with formic acid $(\geq 99 \%)$ and stored at $-21{ }^{\circ} \mathrm{C}$ to prevent further degradation processes. Organic acids were analyzed after centrifugation by gas chromatography (GC) (CP 9001, FID, SGE HT5, $300{ }^{\circ} \mathrm{C}$, Chrompack Inc., USA). Samples of 
Table 1 Substrate characteristics prior to start of the experiments

\begin{tabular}{|c|c|c|c|c|c|c|c|c|c|c|}
\hline & & Inoc 1 & Inoc2 & Inoc3 & MS1 & MS2 & MS3 & MS4 & MS5 & MS6 \\
\hline TS & $\% \mathrm{FW}$ & 4.9 & 4.5 & 4.8 & 39.0 & 33.7 & 34.5 & 27.6 & 30.6 & 31.0 \\
\hline VS & $\% \mathrm{TS}$ & 56.3 & 64.3 & 57.1 & 96.4 & 80.5 & 95.5 & 96.7 & 84.5 & 81.0 \\
\hline $\mathrm{C}$ & $\% \mathrm{TS}$ & 38.9 & 39.8 & 39.4 & 45.9 & 46.6 & 45.8 & 47.0 & 46.1 & 46.9 \\
\hline $\mathrm{N}$ & $\% \mathrm{TS}$ & 2.2 & 2.5 & 3.3 & 1.3 & 1.3 & 1.3 & 1.2 & 1.2 & 1.6 \\
\hline $\mathrm{pH}$ & & 8.0 & 7.9 & 8.0 & - & $-\mathrm{n}$. & & & 3.8 & 5.7 \\
\hline VFA/TAC & & 0.067 & 0.056 & 0.063 & & & - n.a. & & 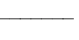 & \\
\hline
\end{tabular}

$\mathrm{C}=$ carbon, $\mathrm{FW}=$ fresh weight, $\mathrm{Inoc}=$ inoculum, $\mathrm{MS}=$ maize silage, $\mathrm{N}=$ nitrogen, $\mathrm{n} . \mathrm{a} .=$ not applicable, n.d. $=$ not determined, $\mathrm{TS}=$ total solids, $\mathrm{VS}=$ volatile solids, $\mathrm{VFA} / \mathrm{TAC}=$ volatile fatty acids $/$ total alkaline capacity experiment E3 were analyzed with a Clarus 580 GC (FID, Elite Wax, $280{ }^{\circ} \mathrm{C}$, PerkinElmer, USA).

In experiment $\mathrm{E} 3$, sby and smy were determined by recording produced gas volumes (MGC-1, Ritter GmbH \& Co. KG, Germany) and methane concentrations (BCP-CH4, BlueSens gas sensor GmbH, Germany). Data were logged hourly with the software BACVis (Version 7.6.2.1, BlueSens gas sensor $\mathrm{GmbH}$, Germany) and corrected to standard conditions (273.15 K and $101.325 \mathrm{kPa})$. The sby and smy are presented in normed $\mathrm{L} \mathrm{kg}^{-1}$ based on VS of the according substrate. The yields refer to the final produced gas volumes within the reactors.

Stable carbon isotopes were evaluated in all maize silages, inocula and reactor mixtures at start and end of the experiments. In addition, nitrogen isotope signatures $\left(\delta^{15} \mathrm{~N}\right)$ were assessed for all maize silages. Analyses were conducted with $0.7 \mathrm{mg}$ of dried and ground samples at the Institute of Food Chemistry, University of Hohenheim. Acetanilide was used as the laboratory standard (isotopic and elemental drift control). Samples were measured with an elemental analyzer (Euro EA $\mathrm{C} / \mathrm{N}$ analyser, EuroVector, Italy), which was coupled to an isotope ratio mass spectrometer (Thermo Finnigan Delta plus Advantage, Thermo Fisher Scientific Inc., USA). This instrument uses magnetic sector as mass analyzer. The applied laboratory reference gases were $\mathrm{CO}_{2}$ and $\mathrm{N}_{2}$ (USGS40 calibrated) (Qi et al. 2003).

Stable isotope signatures are expressed by convention as

$\delta \mathrm{X}(\%$ $)=\frac{\mathrm{R}_{\text {sample }}-\mathrm{R}_{\text {standard }}}{\mathrm{R}_{\text {standard }}} \times 1000$

where $\mathrm{X}$ is ${ }^{13} \mathrm{C}$ or ${ }^{15} \mathrm{~N}$ and $\mathrm{R}$ is the corresponding isotope ratio of ${ }^{13} \mathrm{C} /{ }^{12} \mathrm{C}$ or ${ }^{15} \mathrm{~N} /{ }^{14} \mathrm{~N}$. The isotope signatures are referred to $\mathrm{R}_{\text {standard, }}$ being the international PDB (Pee Dee Belemnite) standard of 0.0112372 (Craig 1953) for $\delta^{13} \mathrm{C}$ and atmospheric $\mathrm{N}_{2}$ of 0.3663 for $\delta^{15} \mathrm{~N}$ (Junk and Svec 1958).

The gross carbon degradation of the reactor mixtures $(\mathrm{C}$ $\operatorname{deg}_{\text {gross }}$ ) was determined by carbon mass balances at start and end of the experiment according to

$\mathrm{C} \mathrm{deg} \operatorname{gross}_{\text {g }}(\%)=\frac{\mathrm{C} \mathrm{mass}_{\text {mix start }}-\mathrm{C} \text { mass }_{\text {mix end }}}{\mathrm{C} \text { mass }_{\text {mix start }}} \times 100$
Generally, the carbon mass of mixtures $\left(\mathrm{C}\right.$ mass $\left._{\text {mix }}\right)$, maize silage $\left(\mathrm{C}\right.$ mass $\left._{\mathrm{MS}}\right)$ and inoculum $\left(\mathrm{C} \mathrm{mass}_{\text {Inoc }}\right)$ was analysed by mass balances according to

$\mathrm{C}^{\operatorname{mass}_{\mathrm{A}}}(\mathrm{g})=\mathrm{FW}_{\mathrm{A} \mathrm{B}} \times \mathrm{TS}_{\mathrm{A} \mathrm{B}} \times \mathrm{C}_{\mathrm{A} \mathrm{B}}$

with $A=$ exclusively mix, MS or Inoc and $B=$ exclusively start or end of the experiment. This formula included the fresh weight (FW in g), the percentage of total solids (TS in \% FW) and carbon concentrations ( $\mathrm{C}$ in \% TS) of the samples.

For elucidating the maize-bound carbon degradation on the basis of the common gross carbon degradation ( $\mathrm{C} \operatorname{deg}_{\mathrm{MS}}$ ) we used the following equation:

$$
\begin{aligned}
\mathrm{C} & \operatorname{deg}_{\mathrm{MS}}(\%) \\
= & \frac{\mathrm{C} \text { mass }_{\mathrm{MS} \text { start }}-\left(\mathrm{C} \text { mass }_{\mathrm{mix} \text { end }}-\mathrm{C} \text { mass }_{\text {Inoc end }}\right)}{\mathrm{C} \text { mass }_{\mathrm{MS} \text { start }}} \\
& \times 100
\end{aligned}
$$

As the carbon mass of the maize silage is not directly detectable at the end of the experiment, it was approximated by an indirect approach. Therefore, the carbon mass of the con-

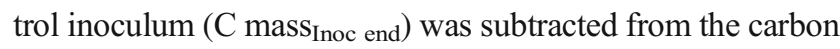
mass of the reactor mixture at the end of the experiment $(\mathrm{C}$ mass $_{\text {mix end }}$ ).

The calculation of net carbon degradation was based on a new approach, focusing on stable isotope fractionation. The isotopic fractionation provides information about the contribution of one source to a mixing pool. The stable carbon isotope fraction $\left(f_{\mathrm{MS}}\right)$ of the maize silages in the according pool was identified by applying a stable isotope mixing model, modified after Werth and Kuzyakov (2010). The fraction was determined by the $\delta^{13} \mathrm{C}$ values of the respective mixture $\left(\delta^{13} \mathrm{C}_{\text {mix }}\right)$, inoculum $\left(\delta^{13} \mathrm{C}_{\text {Inoc }}\right)$ and maize silage $\left(\delta^{13} \mathrm{C}_{\mathrm{MS}}\right)$.

$f_{\text {MS } A}=\frac{\delta^{13} C_{\text {mix } A}-\delta^{13} C_{\text {Inoc } A}}{\delta^{13} C_{\text {MS start }}-\delta^{13} C_{\text {Inoc } A}}$

With $A=$ exclusively start or end of the experiment. The values for inocula were taken from the control reactors. Using the information of the analyzed maize silage fractions $\left(f_{\mathrm{MS}}\right)$ 
on the mass balance of the mixture $\left(\mathrm{C}\right.$ mass $\left.s_{\text {mix }}\right)$ allows the determination of the maize silage carbon mass at start ( $\mathrm{C}$ mass $\left.f_{\mathrm{MS} \text { start }}\right)$ and end ( $\mathrm{C}$ mass $\left.f_{\mathrm{MS} \text { end }}\right)$ of the experiments.

$\mathrm{C}$ mass $f_{\mathrm{MS} \mathrm{A}}(\mathrm{g})=\mathrm{C}$ mass $_{\text {mix A }} \times f_{\mathrm{MS} \mathrm{A}}$

With $A=$ exclusively start or end of the experiment. This information can further be used to calculate the net carbon degradation of maize silage $\left(\mathrm{C} \mathrm{deg}_{\text {net }}\right)$ in a reactor.

$\mathrm{C} \operatorname{deg}_{\text {net }}(\%)=\frac{\mathrm{C} \text { mass } f_{\mathrm{MS} \text { start }}-\mathrm{C} \text { mass } f_{\mathrm{MS} \text { end }}}{\mathrm{C} \text { mass } f_{\mathrm{MS} \text { start }}} \times 100$

\section{Statistical analysis}

Wilcoxon signed-rank tests were applied to find significant differences $(p<0.05)$ between experiments E1 and E2. This study considered all carbon degradation determination approaches $\mathrm{C} \operatorname{deg}_{\text {gross }}, \mathrm{C} \operatorname{deg}_{\mathrm{MS}}, \mathrm{C} \operatorname{deg}_{\text {net }}$ and $\delta^{13} \mathrm{C}$ values at start and end of the experiments. Mean values (Ø) of the degradation determination methods and $\delta^{13} \mathrm{C}$ are given with standard deviation. The software SPSS 20 (SPSS Inc., USA) was used for statistical analysis. Diagrams were generated with Microsoft Excel 2010.

\section{Results}

\section{Digestion parameters}

Digestion parameters differed slightly between reactors from experiment E1 and E3. In experiment E1, all reactors showed $\mathrm{pH}$ values ranging from 7.1 to 7.9 during the course of the experiment (Fig. 2). The VFA/TAC values ranged from 0.03 to 0.35 and developed relatively similar within all reactors. The maximum VFA/TAC value was found with 0.35 in reactor R2 (MS1) on day four. As expected, the $\mathrm{pH}$ levels developed according to the VFA/TAC values together with slightly different organic acid concentrations. On day one of experiment E1, acetic acid concentrations ranged from $3.5 \mathrm{~g} \mathrm{~L}^{-1}$ to $1.9 \mathrm{~g} \mathrm{~L}^{-1}$. The highest acetic acid concentrations were found in reactor R2 (MS1) and R3 (MS2) with $5.3 \mathrm{~g} \mathrm{~L}^{-1}$ and $4.7 \mathrm{~g} \mathrm{~L}^{-1}$, respectively. Highest propionic and butyric acid concentrations showed values of $2.0 \mathrm{~g} \mathrm{~L}^{-1}$ and $0.8 \mathrm{~g} \mathrm{~L}^{-1}$, respectively.

In experiment $\mathrm{E} 3$, reactors with maize silage MS6 showed higher $\mathrm{pH}$ values on day one compared to reactors with maize silage MS5. The VFA/TAC showed values of 0.18 (R3) and 0.15 (R4) on day seven in reactors with maize silage MS6, while both reactors with maize silage MS5 showed values of 0.04 . Acetic and propionic acid concentrations were found in reactors with maize silage MS6 on day seven, but were already depleted in reactors with maize silage MS5.

\section{Specific biogas and methane yields}

Maize silage MS5 showed higher cumulated sby of $708 \mathrm{~L} \mathrm{~kg}^{-1}$ and $702 \mathrm{~L} \mathrm{~kg}^{-1}$ than MS6 with $648 \mathrm{~L} \mathrm{~kg}^{-1}$ and $621 \mathrm{~L} \mathrm{~kg}^{-1}$ (Fig. 3). The average methane concentration in the reactors ranged from $61 \pm 7 \%$ to $69 \pm 10 \%$. The cumulated smy was also higher in reactors containing maize silage MS5 with $461 \mathrm{~L} \mathrm{~kg}^{-1}$ and $392 \mathrm{~L} \mathrm{~kg}^{-1}$ compared to reactors containing maize silage MS6 with $360 \mathrm{~L} \mathrm{~kg}^{-1}$ and $352 \mathrm{~L} \mathrm{~kg}^{-1}$. Reactors with maize silage MS6 produced $7.6 \%$ to $12.2 \%$ lower sby and $8.3 \%$ to $23.8 \%$ lower smy, respectively, than reactors with maize silage MS5. A shift in the steepness of sby and smy graph was visible. For reactors with maize silage MS5 the steepness changed from day six to seven and for reactors with maize silage MS6 on day eight to nine.

\section{Stable isotopes}

Maize silages MS1 to MS4 showed $\delta^{13} \mathrm{C}$ values from -12.16 $\% o$ to $-13.07 \%$ (Table 2). The inocula Inoc1 and Inoc2 had $\delta^{13} \mathrm{C}$ values of $-27.11 \%$ and $-26.84 \%$, respectively. In experiment E3, maize silage MS5 and MS6 showed $\delta^{13} \mathrm{C}$ values of $-12.37 \%$ and $-18.63 \%$, respectively, and inoculum Inoc3 a $\delta^{13} \mathrm{C}$ value of $-17.58 \%$.

The reactor mixtures of experiments E1 and E2 showed higher $\delta^{13} \mathrm{C}$ values compared to inocula Inoc1 and Inoc2. In experiment $\mathrm{E} 1\left(\mathrm{MS}_{\text {fresh }}\right)$ mixtures showed mean $\delta^{13} \mathrm{C}$ values of $-21.98 \pm 0.11 \%$ at the start $\left(\delta^{13} \mathrm{C}_{\text {mix start }}\right)$ and $-25.68 \pm$ $0.20 \%$ at the end $\left(\delta^{13} \mathrm{C}_{\text {mix end }}\right)$ of the experiment (Fig. 4). In experiment $\mathrm{E} 2$ with $\mathrm{MS}_{\mathrm{impaired}}$, the mixtures showed mean $\delta^{13} \mathrm{C}_{\text {mix start }}$ values of $-23.60 \pm 0.78 \%$ and mean $\delta^{13} \mathrm{C}_{\text {mix }}$ end values of $-25.84 \pm 0.37 \%$ o. In both experiments $\delta^{13} \mathrm{C}_{\text {mix }}$ end values were more negative compared to the $\delta^{13} \mathrm{C}_{\text {mix start }}$ values. Also the $\delta^{13} \mathrm{C}_{\text {Inoc end }}$ values of Inoc1, Inoc2 and Inoc3 were more negative compared to the $\delta^{13} \mathrm{C}_{\text {Inoc start }}$ values. $\delta^{13} \mathrm{C}_{\text {mix start }}$ values were significantly more negative in experiment $\mathrm{E} 2$ compared to experiment $\mathrm{E} 1(\mathrm{Z}=-2.37, p=0.02)$.

\section{Carbon degradations}

As expected, the carbon mass in each reactor was higher at the

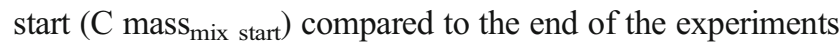
(C mass ${ }_{\text {mix end }}$ (Table 3). Similar results were found for the carbon mass of the maize silages ( $\mathrm{C}$ mass $\left._{\mathrm{MS}}\right)$. Inoculum Inoc1

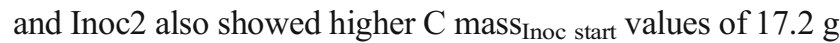
and $16.2 \mathrm{~g}$ compared to $\mathrm{C}$ mass Inoc end $_{\text {values of } 13.1 \mathrm{~g} \text { and }}$ $14.8 \mathrm{~g}$, respectively. The carbon mass determination of maize silages via isotopic fractionation in experiment $\mathrm{E} 1$ resulted in higher starting values (C mass $f_{\mathrm{MS} \text { start }}$ ), ranging from $8.4 \mathrm{~g}$ to $9.2 \mathrm{~g}$, compared to $\mathrm{C}$ mass $_{\mathrm{MS}}$ start with $6.0 \mathrm{~g}$ to $6.1 \mathrm{~g}$. In experiment E2, C mass $f_{\mathrm{MS}}$ start showed relatively lower values compared to the determined $\mathrm{C}$ mass $\mathrm{MS}$ start values (exception found in R7).Analyzing the different carbon 
degradation determination approaches, $\mathrm{C}$ deg gross values ranged from $31.6 \%$ to $48.7 \%$ in experiment E1, resulting in a mean gross carbon degradation of $39.3 \pm 5.5 \%$. Significantly

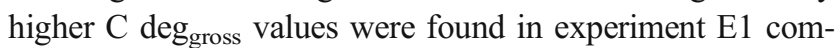
pared to experiment $\mathrm{E} 2(\mathrm{Z}=-2.20, p=0.03)$ with a $\mathrm{C}$ deg $_{\text {gross }}$ mean of $27.7 \pm 4.8 \%$. The carbon degradations of experiment E3 showed $\mathrm{C}$ deg gross values ranging from $61.2 \%$ to $62.9 \%$.

Values for $\mathrm{C} \operatorname{deg}_{\mathrm{MS}}$ ranged from $49.5 \%$ to $85.6 \%$ (mean $65.6 \pm 14.5 \%$ ) in experiment E1 and from $46.7 \%$ to $81.1 \%$ (mean $71.5 \pm 11.9 \%$ ) in experiment E2. No significant differences were found for $\mathrm{C} \operatorname{deg}_{\mathrm{MS}}$ between experiments $\mathrm{E} 1$ and E2. Experiment E3 showed $\mathrm{C} \operatorname{deg}_{\mathrm{MS}}$ values ranging from $79.5 \%$ to $95.3 \%$.

The new stable isotope approach for net carbon degradation determination showed $\mathrm{C} \operatorname{deg}_{\text {net }}$ values ranging from $75.4 \%$ to $86.5 \%$ (mean $81.1 \pm 3.5 \%$ ) in experiment $\mathrm{E} 1$. Experiment E2 showed significantly lower $\mathrm{C}$ deg net values $(\mathrm{Z}=-2.37, p=0.02$ ) ranging from $58.4 \%$ to $79.2 \%$ (mean $67.7 \pm 8.4 \%$ ). The standard deviation indicated a higher variance in experiment E2 compared to experiment E1. The carbon degradation determination method using stable isotopes $\mathrm{C}$ $\operatorname{deg}_{\text {net }}$ was found to be not applicable in experiment E3.

\section{Discussion}

\section{Digestion parameters}

Determined digestion parameters did not show any inhibition within the conducted experiments. Different developments of digestion parameters between reactors of experiment E1 and E3 might be a result of different activities of inocula Inoc1 and Inoc3. The digestion parameters within all reactors of experiment E1 indicated relatively similar anaerobic digestion processes. Metabolic inhibitions due to high VFA/TAC or low $\mathrm{pH}$ values (Voß et al. 2009) were not detected in experiments E1 and E3. Acid production is the key intermediate during anaerobic digestion. In this study, acetic acid showed the highest concentrations of all analyzed acids (c.f. Mösche and Jördening 1999). Slightly different acetic acid concentrations at day one of the experiments indicated variabilities within the applied maize silages. Acetic acid is a main product of heterofermentative lactic acid bacteria during ensiling of biogas crops. As ensiling is an uncontrolled process (Hermann et al. 2011), different acetic acid concentrations were likely within maize silages after $24 \mathrm{~h}$ degradation. McDonald et al. (1991) stated that $\mathrm{pH}$ values less than 4.0 indicate a good silage quality, which was present in maize silages MS5 $(\mathrm{pH}=3.78)$ of experiment $\mathrm{E} 3$. The higher acetic acid concentrations found in reactors with maize silage MS5, compared to maize silage MS6, might be a result of beneficial ensiling processes during lactic acid fermentation (McDonald et al. 1991). Possibly, this influenced the efficiency of the
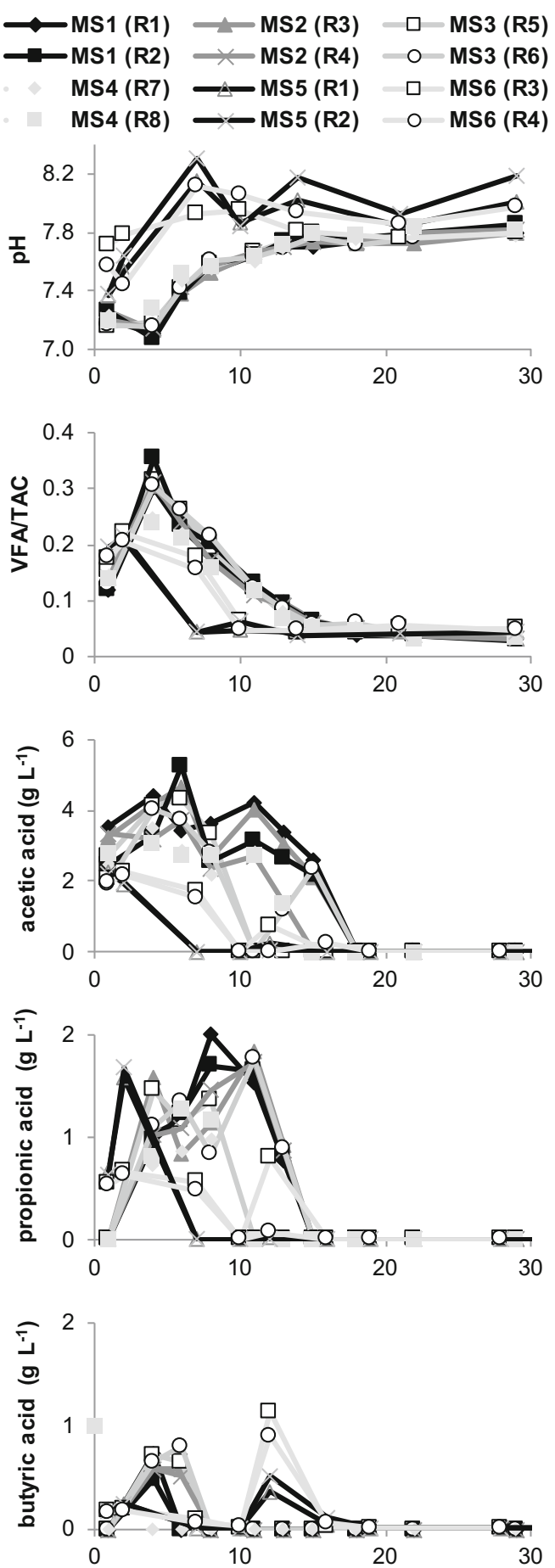

Fig. 2 Digestion parameters of different maize silages (MS) in experiments E1 and E3 (first 29 days depicted). R = reactor, VFA/ $\mathrm{TAC}=$ volatile fatty acids $/$ total alkaline capacity buffer. Note different y-axis scaling

conversion processes in maize silage MS6, as indicated by higher $\mathrm{pH}$ values, and slowed the anaerobic digestion metabolism. As a result, this led to a prolonged presence of acetic acid in reactors with maize silage MS6. Our results indicated that digestion parameters in experiment E3 were mainly influenced by maize silage quality. 
Fig. 3 Specific biogas (sby) and methane yields (smy) of maize silages MS5 and MS6 in experiment E3. $\mathrm{R}=$ reactor. Unit based on volatile solids

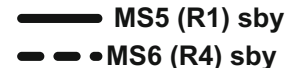

-... MS5 (R2) sby

MS5 (R1) smy

MS6 (R3) sby

MS5 (R2) smy

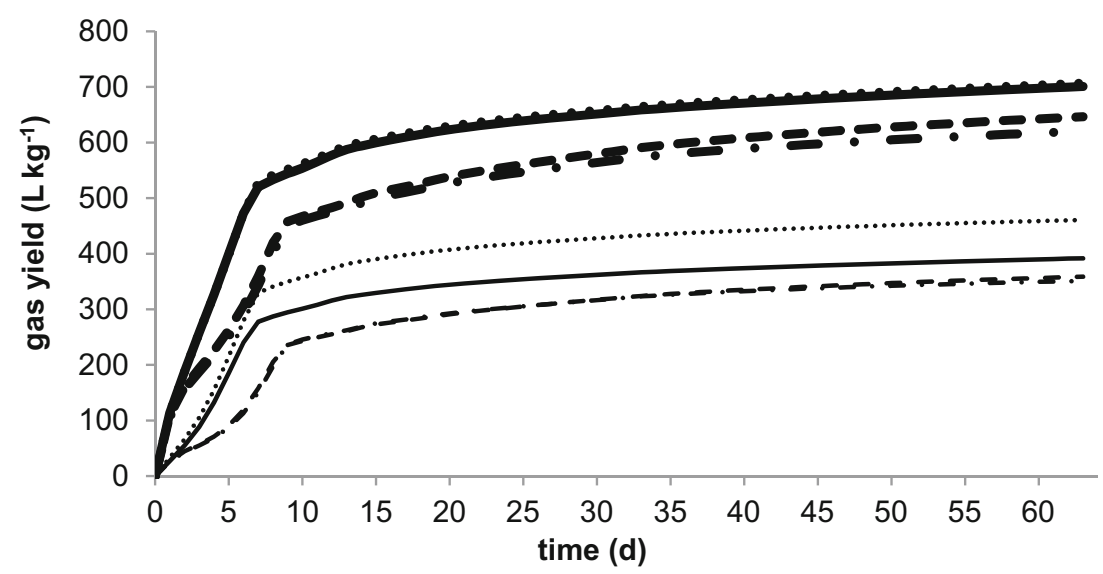

\section{Specific biogas and methane yield}

sby, smy and methane concentrations were similar to literature-values found for maize silage (c.f. Amon et al. 2007). Standard protocols for assignment of specific yields (VDI 2006) require that inoculum has a low residual biogas production potential at the start of the experiment, which was the case in all experiments. Considering the produced biogas volume at day 64 , already $89.0 \%$ (R4) to $92.6 \%$ (R2) of the final biogas volume was produced after 29 days. This indicated that substrate degradation was already performed within the first 29 days. Of the analyzed acids, acetic acid has the highest conversion rates to methane (Wang et al. 2009). Herrmann et al. (2011) and Vervaeren et al. (2010) showed a close relationship of acetic acid concentrations to the smy. The effect of acetic acid on the biogas and methane production was also visible in experiment $\mathrm{E} 3$. With depletion of acetic acid the steepness of the sby and smy graphs changed visibly. Higher sby and smy were found for reactors with maize silage MS5 compared to reactors with MS6, despite higher variabilities between reactors R1 and R2 of maize silage MS5. sby and smy differences are likely to be a result of subsample variabilities within MS5. The higher sby and smy of maize silage MS5 compared to maize silage MS6 might be a result of the

Table $2 \delta^{13} \mathrm{C}$ and $\delta^{15} \mathrm{~N}$ stable isotope values of maize silages MS1 to MS6 (n =3)

\begin{tabular}{lll}
\hline Maize silage & $\delta^{13} \mathrm{C}(\% \circ)$ & $\delta^{15} \mathrm{~N}(\% \circ)$ \\
\hline MS1 & $-12.56 \pm 0.14$ & $7.49 \pm 0.09$ \\
MS2 & $-13.07 \pm 0.21$ & $6.80 \pm 0.26$ \\
MS3 & $-12.58 \pm 0.15$ & $6.62 \pm 0.22$ \\
MS4 & $-12.16 \pm 0.07$ & $6.17 \pm 0.08$ \\
MS5 & $-12.37 \pm 0.09$ & $6.54 \pm 0.70$ \\
MS6 & $-18.58 \pm 0.67$ & $6.22 \pm 0.32$ \\
\hline
\end{tabular}

ensilage of sunflower plants within maize silage MS6. Sunflowers generally show lower biogas potentials compared to maize (Amon et al. 2007). Additionally, this difference can be related to better ensilage processes and good storage conditions of maize silage MS5 (Oude Elferink and Driehuis 2000).

\section{Stable isotope signatures}

The investigated maize silages showed $\delta^{13} \mathrm{C}$ values corresponding to literature values for maize (Gleixner et al. 1999; Haubert et al. 2009) and maize silages (Schwertl et al. 2005). An exception was found in maize silage MS6, which showed more negative $\delta^{13} \mathrm{C}$ values. As $\mathrm{C}_{3}$-plants, sunflowers have a $\delta^{13} \mathrm{C}$ of about $-28 \%$ (Zhu and Cheng 2011), which explains the more negative values found in maize silage MS6 due to mixed ensilage. The $\delta^{13} \mathrm{C}$ values of MS6 indicated that more than $5 \%(\mathrm{FW})$ sunflowers were ensiled with the maize silage. The study showed a variability of $\delta^{13} \mathrm{C}$ values in different agricultural maize silages (Table 2). Such variations can be influenced by various parameters, including the cultivation system. For instance, Haubert et al. (2009) found more negative $\delta^{13} \mathrm{C}$ values in maize leaves $(-13.3 \pm 0.06 \%$ ) cultivated under organic farming standards, compared to conventionally cultivated maize $\left(-12.9 \pm 0.02 \%\right.$ ). Differences in $\delta^{15} \mathrm{~N}$ values of maize silages MS1 to MS6 might be a result of variable amounts of organic and mineral fertilizers applied for maize cultivation (EU 2007; Shearer et al. 1974).

Inocula Inoc1 and Inoc2 showed relatively similar $\delta^{13} \mathrm{C}$ values at the start of each experiment. The $\delta^{13} \mathrm{C}$ differences between these inocula (Inoc1 and Inoc2) compared to inoculum Inoc3 originated from different substrates utilized in the according biogas plants. Inocula Inoc1 and Inoc 2 originated from an organic farm. Such biogas plants are generally prone to utilize high amounts of $\mathrm{C}_{3}$ plants and low amounts of maize silages $\left(\mathrm{C}_{4}\right.$ plants) (Einfalt and Kazda 2016). This resulted in 
Fig. $4 \delta^{13} \mathrm{C}$ values of reactor mixtures (mix) and inocula (Inoc) at start and end of experiments $\mathrm{E} 1, \mathrm{E} 2$ and $\mathrm{E} 3 . \mathrm{MS}=$ maize silage, $\mathrm{R}=$ reactor

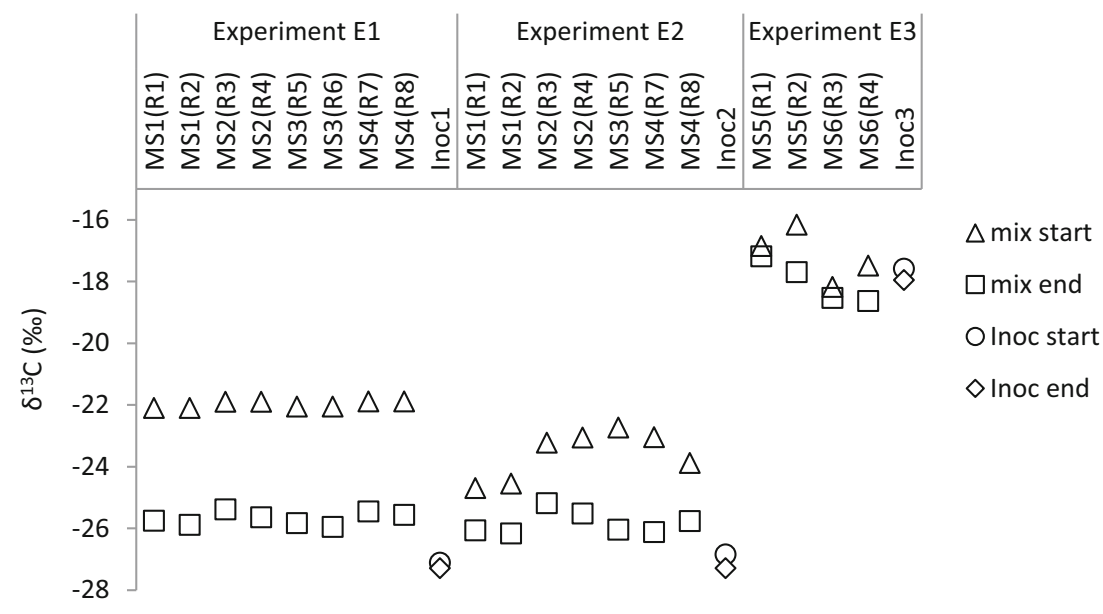

Table 3 Carbon mass balance and applied carbon degradation determination methods

\begin{tabular}{|c|c|c|c|c|c|c|c|c|c|c|c|}
\hline & & & MS1 & & MS2 & & MS3 & & MS4 & & \\
\hline & & & $\mathrm{R} 1$ & $\mathrm{R} 2$ & R3 & $\mathrm{R} 4$ & R5 & R6 & R7 & $\mathrm{R} 8$ & $\varnothing$ \\
\hline \multirow{9}{*}{${ }^{\mathrm{E} 1}\left(\mathrm{MS}_{\mathrm{fresh}}\right)$} & $\mathrm{C}$ mass $_{\text {mix }}$ & $\mathrm{g}$ & 24.4 & 24.4 & 23.6 & 23.6 & 27.1 & 27.1 & 25.1 & 25.1 & \\
\hline & $\mathrm{C}$ mass $_{\text {mix }}$ & $\mathrm{g}$ & 14.7 & 14.5 & 16.1 & 15.6 & 15.9 & 13.9 & 16.1 & 14.3 & \\
\hline & $\begin{array}{l}\text { end } \\
\mathrm{C} \mathrm{deg} \\
\text { gross }\end{array}$ & $\%$ & 39.6 & 40.3 & 31.6 & 33.8 & 41.3 & 48.7 & 35.9 & 43.1 & $39.3 \pm 5.5$ \\
\hline & $\underset{\text { start }}{\mathrm{C} \text { mass }_{\mathrm{MS}}}$ & $\mathrm{g}$ & 6.0 & 6.0 & 6.1 & 6.1 & 6.0 & 6.0 & 6.1 & 6.1 & \\
\hline & $\mathrm{C}$ mass $_{\mathrm{MS}}$ & $\mathrm{g}$ & 1.7 & 1.5 & 3.1 & 2.5 & 2.9 & 0.9 & 3.0 & 1.2 & \\
\hline & $\mathrm{C} \mathrm{deg} \mathrm{gS}_{\mathrm{MS}}$ & $\%$ & 72.3 & 75.3 & 49.5 & 58.1 & 52.2 & 85.6 & 50.9 & 80.6 & $65.6 \pm 14.5$ \\
\hline & $\begin{array}{l}\mathrm{C} \text { mass } \\
f_{\mathrm{MS} \text { start }}\end{array}$ & $\mathrm{g}$ & 8.4 & 8.4 & 8.8 & 8.8 & 9.2 & 9.2 & 9.0 & 9.0 & \\
\hline & $\begin{array}{l}\mathrm{C} \text { mass } \\
f_{\mathrm{MS} \text { end }}\end{array}$ & g & 1.5 & 1.4 & 2.2 & 1.8 & 1.5 & 1.2 & 2.0 & 1.7 & \\
\hline & $\mathrm{C}$ deg $g_{\text {net }}$ & $\%$ & 81.6 & 83.4 & 75.4 & 79.3 & 83.2 & 86.5 & 77.7 & 81.4 & $81.1 \pm 3.5$ \\
\hline \multirow{9}{*}{$\begin{array}{l}\text { E2 } \\
\quad\left(\mathrm{MS}_{\text {impa- }}\right. \\
\quad \text { ired })\end{array}$} & $\underset{\text { start }}{\mathrm{C} \text { mass }_{\text {mix }}}$ & $\mathrm{g}$ & 23.3 & 20.7 & 22.9 & 26.2 & 21.2 & n.d. & 25.9 & 21.7 & \\
\hline & $\mathrm{C}$ mass $_{\operatorname{mix}}$ & g & 16.7 & 16.0 & 17.0 & 16.5 & 16.1 & n.d. & 18.1 & 16.1 & \\
\hline & $\begin{array}{l}\text { end } \\
\mathrm{C} \text { deg gross }_{\text {gro }}\end{array}$ & $\%$ & 28.4 & 23.1 & 25.8 & 37.0 & 23.9 & n.d. & 30.1 & 25.8 & $27.7 \pm 4.8$ \\
\hline & $\mathrm{C}$ mass $_{\mathrm{MS}}$ & g & 6.0 & 6.0 & 7.3 & 7.3 & 6.0 & n.d. & 6.1 & 6.1 & \\
\hline & $\underset{\text { end }}{\mathrm{C} \text { mass }_{\mathrm{MS}}}$ & $\mathrm{g}$ & 1.9 & 1.1 & 2.2 & 1.7 & 1.3 & n.d. & 3.3 & 1.3 & \\
\hline & $\mathrm{C} \mathrm{deg}_{\mathrm{MS}}$ & $\%$ & 68.5 & 81.1 & 69.8 & 76.9 & 78.4 & n.d. & 46.7 & 78.9 & $71.5 \pm 11.9$ \\
\hline & $\begin{array}{l}\mathrm{C} \text { mass } \\
f_{\mathrm{MS} \text { start }}\end{array}$ & $\mathrm{g}$ & 3.5 & 3.3 & 6.0 & 7.2 & 5.9 & n.d. & 6.9 & 4.5 & \\
\hline & $\begin{array}{l}\mathrm{C} \text { mass } \\
f_{\mathrm{MS} \text { end }}\end{array}$ & g & 1.4 & 1.2 & 2.5 & 2.1 & 1.3 & n.d. & 1.4 & 1.7 & \\
\hline & $\mathrm{C} \mathrm{deg}$ net & $\%$ & 60.3 & 63.7 & 58.4 & 71.5 & 77.7 & n.d. & 79.2 & 63.1 & $67.7 \pm 8.4$ \\
\hline
\end{tabular}

MS = maize silage, n.d. = not determined, $\mathrm{R}=$ reactor, $f=$ stable isotope fractionation

Carbon mass balance shown for mixtures $\left(\mathrm{C}\right.$ mass $\left.{ }_{\text {mix }}\right)$, maize silages $\left(\mathrm{C}\right.$ mass $\left._{\mathrm{MS}}\right)$ and applied isotopic fractionation model (C mass $f_{\mathrm{MS}}$ ) for each reactor $(\mathrm{R})$ at the start and end of experiments $\mathrm{E} 1$ and $\mathrm{E} 2$. Maize silages MS1 MS4 were applied in fresh $\left(\mathrm{MS}_{\text {fresh }}\right)$ and impaired storage $\left(\mathrm{MS}_{\text {impaired }}\right)$ conditions. Applied carbon degradation determination methods include gross carbon degradation of mixtures $\left(\mathrm{C} \operatorname{deg}_{\text {gross }}\right)$, approximation of maize silage degradation ( $\mathrm{C}$ deg $_{\mathrm{MS}}$ ) and net carbon degradation with applied isotope fractionation model ( $\mathrm{C}$ deg $\left._{\text {net }}\right)$. Mean values $(\varnothing)$ of the degradation determination methods are given with standard deviation 
$\delta^{13} \mathrm{C}$ values more depleted in the ${ }^{13} \mathrm{C}$ isotope than inoculum Inoc3, which originated from a conventional farm's biogas plant that utilized preferably maize silage.

The maize silages with impaired storage conditions MS1 to

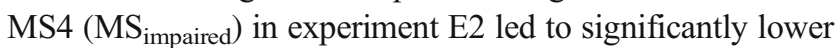
$\delta^{13} \mathrm{C}_{\text {mix start }}$ values compared to the same maize silages in experiment $\mathrm{E} 1\left(\mathrm{MS}_{\text {fresh }}\right)$. This indicated that the $\delta^{13} \mathrm{C}_{\text {mix start }}$ values were significantly influenced by impaired storage conditions of the maize silages. Furthermore, this opens possibilities to draw conclusions about the maize silages' storage conditions by negatively shifted $\delta^{13} \mathrm{C}$ values in reactor mixture. The relatively high variation in $\delta^{13} \mathrm{C}_{\text {mix }}$ start values of the maize silages in experiment $\mathrm{E} 2$ indicated that impaired storage conditions influence $\delta^{13} \mathrm{C}$ compositions of maize silages differently. This led to different ${ }^{13} \mathrm{C}$-depleted maize silages in reactor mixtures at the start of experiment E2. Also relatively high variations between reactor duplicates occurred in experiment E2, indicating high inner substrate variabilities in terms of $\delta^{13} \mathrm{C}$ values.

Despite different $\delta^{13} \mathrm{C}_{\text {mix start }}$ values between experiments $\mathrm{E} 1$ and E2, relatively similar $\delta^{13} \mathrm{C}_{\text {mix }}$ end values were found in both experiments. The $\delta^{13} \mathrm{C}_{\text {mix end }}$ values of experiments E1 and $\mathrm{E} 2$ were clearly shifted towards the $\delta^{13} \mathrm{C}_{\text {Inoc }}$ values. Most biochemical processes discriminate against the heavier carbon isotope creating products depleted in ${ }^{13} \mathrm{C}$ and leaving reactants enriched in ${ }^{13} \mathrm{C}$ (Conrad 2005; Fry 2006; Werth and Kuzyakov 2010). So far, such results were mainly observed in experiments of either pure $\mathrm{C}_{3}$ or pure $\mathrm{C}_{4}$ samples. In experiment $\mathrm{E} 1$ and $\mathrm{E} 2 \mathrm{C}_{3}$ and $\mathrm{C}_{4}$ sources were mixed in the reactors and resulted in a negative shift of all $\delta^{13} \mathrm{C}_{\text {mix }}$ and $\delta^{13} \mathrm{C}_{\text {Inoc }}$ values between start and end of the experiments. This indicated a ${ }^{13} \mathrm{C}$ depletion of the reactant and a ${ }^{13} \mathrm{C}$ discrimination during the degradation process. The ${ }^{13} \mathrm{C}$ depletion in the reactor mixtures was therefore linked to the degradation of the maize silage. Similar results were found by Laukenmann et al. (2009) who digested $\mathrm{C}_{3}$ and $\mathrm{C}_{4}$ mixtures in batch biogas systems and analyzed $\delta^{13} \mathrm{C}$ values of produced methane and $\mathrm{CO}_{2}$. The authors found a shift of the gases towards more negative $\delta^{13} \mathrm{C}$ values for the first five days, leaving the mixture enriched in ${ }^{13} \mathrm{C}$ isotopes. This was also found by Francioso et al. (2010) who reported a positive shift of $\delta^{13} \mathrm{C}$ values in the mixtures during the first six days. However, in the proceeding experimental time of Laukenmann et al. (2009) the gases shifted towards less positive $\delta^{13} \mathrm{C}$ values, demonstrating a depletion of the ${ }^{13} \mathrm{C}$ isotopes in the mixture. This occurred despite methane formation, which is a strongly ${ }^{13} \mathrm{C}$ discriminating biodegradation process (methane $\delta^{13} \mathrm{C}$ values from $-47 \%$ to $-89 \%$ ) (Krzycki et al. 1987). As Laukenmann et al. (2009) showed, exhausted gases were isotopically depleted at the beginning of the experiment. During this time the mixtures became enriched in ${ }^{13} \mathrm{C}$. However, as the carbon pool is limited in a batch digestion experiment, the ${ }^{13} \mathrm{C}$ enriched mixture became eventually metabolized to methane and $\mathrm{CO}_{2}$ which, in turn, shows increasingly negative $\delta^{13} \mathrm{C}$ values. These results indicated a depletion of ${ }^{13} \mathrm{C}$ in the reactor mixtures of anaerobic batch digestion experiments when the carbon pool becomes increasingly limited.The negative shift of all $\delta^{13} \mathrm{C}_{\text {mix }}$ and $\delta^{13} \mathrm{C}_{\text {Inoc }}$ values at the end of the experiment was also the result of variable degradability of different biochemical fractions. Sugars, starch, proteins and organic acids are considered easily degradable in anaerobic digestions, while having less negative $\delta^{13} \mathrm{C}$ values (Bowling et al. 2008; Hobbie and Werner 2004). Lignin and lipids are difficult substrates concerning degradability (Chen et al. 2008) and show generally more depleted $\delta^{13} \mathrm{C}$ values (Bowling et al. 2008; Hobbie and Werner 2004). Therefore, the negative shift of $\delta^{13} \mathrm{C}$ in the reactor mixtures during the experimental retention time is a result of the continuous depletion of maize silage and successively increasing amounts of biochemical fractions of low degradability.

Also all depleted $\delta^{13} \mathrm{C}_{\text {mix end }}$ values indicated more positive values compared to the according $\delta^{13} \mathrm{C}_{\text {Inoc }}$ values. This indicated an incomplete degradation of the maize silages after 29 days. On a long term run, as present in continuously fed reactors, it is likely that the $\delta^{13} \mathrm{C}_{\text {mix }}$ values will become more positive and close to $\delta^{13} \mathrm{C}$ values of the feedstock.

\section{Carbon degradation assessment}

Assessing the carbon degradation by different methodologies showed high variabilities in the determined values. The mean

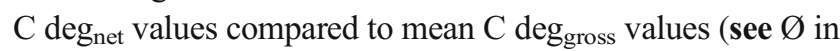
Table 3) were increased by $42 \%$ and $40 \%$ in experiments E1 and $\mathrm{E} 2$, respectively. The lower $\mathrm{C} \operatorname{deg}_{\text {gross }}$ values in experiments E1 and E2, compared to $\mathrm{C} \operatorname{deg}_{\text {net }}$ was due to the fact, that the carbon mass balance of the reactor mixtures included the carbon mass of the inoculum (c.f. equation 2). However, the carbon degradation occurs mainly in the added maize silage while the inoculum ideally only provides the necessary microbial communities and enzymes. All inocula showed relatively low residual biogas potentials prior to experiments, which can be linked to low inner carbon degradation processes. Therefore, the carbon degradation evaluation of the substrate in batch experiments is masked by the quantitatively high amount of carbon in the inoculum, resulting in an underestimation of the actual substrate-bound carbon degradation. Impaired storage conditions of the maize silages resulted in lower $\mathrm{C}$ deg gross $_{\text {gr }}$ of experiment E2 compared to experiment E1. This can be explained as maize silage degradability is negatively influenced by temperature and long storage conditions (Ali et al. 2015). During the impaired storage of the maize silage available carbohydrates are successively degraded. Losses of easily degradable substances (e.g. nonstructural carbohydrates) increased the relative amount of poorly degradable substances (e.g. fibers). Their anaerobic 
degradation is a relatively slow process and needs a long retention time (Golkowska and Greger 2013). Therefore, the relative amount of poorly degradable substances was likely to be higher in $\mathrm{MS}_{\text {impaired }}$, compared to $\mathrm{MS}_{\text {fresh }}$, and resulted in lower carbon degradation over the retention time of 29 days.

The highest $\mathrm{C}$ deg gross and $\mathrm{C} \operatorname{deg}_{\mathrm{MS}}$ values were found in experiment E3 due to retention time of 64 days. Higher degradation efficiency is majorly influenced by increased retention time (Ruile et al. 2015). Additionally, temperature is a key factor in biogas production (Naik et al. 2014; Pap et al. 2015; Sakar et al. 2009) influencing the metabolism of the microorganisms and thus the substrate degradation efficiency (Weiland 2010). As a longer retention time and higher digestion temperatures were present in experiment E3 $\left(42{ }^{\circ} \mathrm{C}\right)$, compared to experiments E1 and E2 $\left(38{ }^{\circ} \mathrm{C}\right)$, conditions in the former are likely to have improved carbon degradation.

The determination of $\mathrm{C} \operatorname{deg}_{\mathrm{MS}}$ is based on an estimation of the available maize silage carbon mass in the reactor mixtures at start and end of the experiment (c.f. equation 4). As C mass $_{\text {MS end }}$ cannot be evaluated directly, it has to be approximated by an indirect approach. Therefore, the carbon mass of inoculum in the control reactor is analyzed at the end of the experiment ( $\mathrm{C}$ mass $\left._{\text {Inoc end }}\right)$. Further, $\mathrm{C}$ mass Inoc end $_{\text {is }}$ subtracted from the carbon mass of the mixture at the end of the experiment $\left(\mathrm{C}\right.$ mass $\left._{\text {mix end }}\right)$. As two different reactors needed to be sampled, priming effects due to additional substrate within the reactor mixtures are not taken into account. The mean $\mathrm{C} \operatorname{deg}_{\mathrm{MS}}$ values indicated slightly higher carbon degradations in experiment E2 compared to experiment E1, albeit not significant. However, the impaired storage conditions of the maize silages (experiment E2) cannot have increased the available total carbon mass in experiment E2. Therefore, the indirect approach for elucidating $\mathrm{C} \operatorname{deg}_{\mathrm{MS}}$ did not show reliable values for the conducted experiments.

The analyzed net carbon degradation $\mathrm{C} \operatorname{deg}_{\text {net }}$ did show applicable on different maize silages, as applied in experiment E1. Despite described variabilities within the substrate characteristics of maize silages prior to the experiment mean net carbon degradation of $81.1 \pm 3.5 \%$ indicated the applicability of this method to maize silages. It furthermore showed that the method can be applied on maize silages of fresh qualities despite inter-substrate variabilities due to differences in cultivation or ensilage. The net carbon degradation $\mathrm{C} \operatorname{deg}_{\text {net }}$ in experiment E2 showed significantly lower values compared to experiment E1. Thus, the artificially reduced qualities in $\mathrm{MS}_{\text {impaired }}$ were indeed detectable by the investigated method, despite their differences in $\delta^{13} \mathrm{C}$ compositions. Additionally, relatively large deviations within $\mathrm{C} \operatorname{deg}_{\text {net }}$ of the duplicates, indicated by high variability of $\delta^{13} \mathrm{C}$, may point out inhomogeneous degradation processes within the reactors. Therefore, the method offers a possibility to determine the quality of maize silages for anaerobic digestion.
The determination of $\mathrm{C}$ deg $_{\text {net }}$ in experiment E3 was not possible. The stable isotope mixing model has to be applied to substrates of pure $\mathrm{C}_{3}$ sources in combination with substrates of pure $\mathrm{C}_{4}$ sources. As inoculum Inoc3 already contained a mixture of $\mathrm{C}_{3}$ and $\mathrm{C}_{4}$ sources, no precise ${ }^{13} \mathrm{C}$ fractionation was determinable. Therefore, the experimental setup design must consist of inocula of biogas reactors utilizing solely $\mathrm{C}_{3}$ plants and pure $\mathrm{C}_{4}$ plant substrates (e.g. maize silages) or vice versa.

By comparing the applied carbon degradation methods, $\mathrm{C}$ $\operatorname{deg}_{\text {net }}$ determination showed higher values compared to $\mathrm{C}$ $\operatorname{deg}_{\text {gross. }}$ As $\mathrm{C} \operatorname{deg}_{\text {net }}$ determination included information about isotope fractionation, it defined the contribution of maize silage to the total mixed carbon pool. Therefore, this information provided a detailed picture about the maize silage fraction and net carbon degradation of the investigated maize silage.

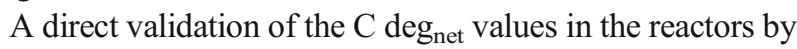
carbon mass balancing is generally not possible. $\mathrm{C}$ deg net $_{\text {net }}$ values can, however, be compared to exhausted biogas. Continuous efflux of carbon-based gasses $\mathrm{CO}_{2}$ and $\mathrm{CH}_{4}$ is a result of continuous carbon degradation. Results from maize silage MS5 in experiment E3 showed that $92.5 \%$ to $92.6 \%$ of the final sby were already produced at day 29 . It has to be considered, that biogas production in E3 was not finally completed after 64 days and poorly degradable substances from inoculum and substrate remained in the reactor. Comparing these with $\mathrm{C}$ deg $_{\text {net }}$ values of $81.1 \pm 3.5 \%$ from E1, a validation of the stable isotope approach can be assumed viable.

\section{Conclusion}

Gross and net carbon degradation was determined by different methodical approaches within different experimental setups. The experiments revealed that net carbon degradation can be determined by including information about isotopic fractionation. The applicability of this method was tested positive on variable maize silages originating from different agricultural farms.

Artificially lowering the maize silage quality by unfavorable storage conditions ( 47 days, $21 \pm 1{ }^{\circ} \mathrm{C}$ ) significantly influenced stable isotope compositions. Expected differences in gross and net carbon degradation showed determinable, despite different carbon isotope signatures. This suggests the use of this method for determination of silage quality.

Gross carbon degradation determinations underestimate the actual substrate-bound carbon degradation. Compared to gross carbon degradation determination, net carbon degradation determination has the advantage to exclude the masking effect of the inoculum. This offers the possibility to implement a standardized stable isotope method for maize-silage bound net carbon degradation determination in anaerobic fermentation. 
Acknowledgments Open Access funding provided by Projekt DEAL. We are grateful for the technical and analytical support by Ellen Salzer and Hans Malchus at UIm University.

\section{Compliance with ethical standards}

Conflict of interest The authors declare that they have no conflict of interest.

Human and animal rights This article does not contain any studies with human participants or animals performed by any of the authors.

Informed consent Informed consent was obtained from all individual participants included in the study.

Open Access This article is licensed under a Creative Commons Attribution 4.0 International License, which permits use, sharing, adaptation, distribution and reproduction in any medium or format, as long as you give appropriate credit to the original author(s) and the source, provide a link to the Creative Commons licence, and indicate if changes were made. The images or other third party material in this article are included in the article's Creative Commons licence, unless indicated otherwise in a credit line to the material. If material is not included in the article's Creative Commons licence and your intended use is not permitted by statutory regulation or exceeds the permitted use, you will need to obtain permission directly from the copyright holder. To view a copy of this licence, visit http://creativecommons.org/licenses/by/4.0/.

\section{References}

Ali M, Cone JW, Khan NA, Hendriks WH, Struik PC (2015) Effect of temperature and duration of ensiling on in vitro degradation of maize silages in rumen fluid. J Anim Physiol Anim Nutr 99:251-257. https://doi.org/10.1111/jpn.12244

Amelung W, Brodowski S, Sandhage-Hofmann A, Bol R (2008). Combining biomarker with stable isotope analyses for assessing the transformation and turnover of soil organic matter. Adv Agron 100:155-250. 10.1016/S0065-2113(08)00606-8

Amon T, Amon B, Kryvoruchko V, Machmüller A, Hopfner-Sixt K, Bodiroza V, Hrbek R, Friedel J, Pötsch E, Wagentristl H, Schreiner M, Zollitsch W (2007) Methane production through anaerobic digestion of various energy crops grown in sustainable crop rotations. Bioresour Technol 98:3204-3212. https://doi.org/10. 1016/j.biortech.2006.07.007

ASTM E70-07 (2015) Standard test method for $\mathrm{pH}$ of aqueous solutions with the glass electrode. ASTM International, West Conshohocken. https://doi.org/10.1520/E0070-07R15

ASTM E1755-01 (2015), Standard test method for ash in biomass, ASTM International, West Conshohocken, 10.1520/E1755-01R15

ASTM E1756-08 (2015), Standard Test Method for Determination of Total Solids in Biomass, ASTM International, West Conshohocken, https://doi.org/10.1520/E1756-08R15

Bisutti I, Hilke I, Raessler M (2004) determination of total organic carbon - an overview of current methods. Trends Anal Chem 23:716-726. https://doi.org/10.1016/j.trac.2004.09.003

Bowling DR, Pataki DE, Randerson JT (2008) Carbon isotopes in terrestrial ecosystem pools and $\mathrm{CO}_{2}$ fluxes. New Phytol 178:24-40. https://doi.org/10.1111/j.1469-8137.2007.02342.x

Brüggemann N, Gessler A, Kayler Z, Keel SG, Badeck F, Barthel M, Boeckx M, Buchmann N, Brugnoli E, Esperschütz J, Gavrichkova O, Ghashghaie J, Gomez-Casanovas N, Keitel C, Knohl A, Kuptz
D, Palacio S, Salmon Y, Uchida Y, Bahn M (2011) Carbon allocation and carbon isotope fluxes in the plant-soil-atmosphere continuum: a review. Biogeosciences 8:3457-3489. https://doi.org/10. 5194/bg-8-3457-2011

Chen Y, Cheng JJ, Creamer KS (2008) Inhibition of anaerobic digestion process: a review. Bioresour Technol 99:4044-4064. https://doi.org/ 10.1016/j.biortech.2007.01.057

Conrad R (2005) Quantification of methanogenic pathways using stable carbon isotopic signatures: a review and a proposal. Org Geochem 36:739-752. https://doi.org/10.1016/j.orggeochem.2004.09.006

Conrad R, Klose M, Yuan Q, Lu Y, Chidthaisong A (2012) Stable carbon isotope fractionation, carbon flux partitioning and priming effects in anoxic soils during methanogenic degradation of straw and soil organic matter. Soil biol. Biochem 49:193-199. https://doi.org/10. 1016/j.soilbio.2012.02.030

Craig H (1953) The geochemistry of the stable carbon isotopes. Geochim Cosmochim Acta 3:53-92. https://doi.org/10.1016/0016-7037(53) 90001-5

Einfalt D, Kazda M (2016) Characterisation of biogas plants on organic farms and potentials for improvement. Org Agric 6:243-254. https:// doi.org/10.1007/s13165-015-0133-3

EU (2007) Council regulation (EC) no 834/2007. European Union, Luxemburg

FNR (2017) Bioenergy in Germany facts and figures 2017. Agency for Renewable Resources, Gülzow-Prüzen

Francioso O, Rodriguez-Estrada MT, Montecchio D, Salomoni C, Caputo A, Palenzona D (2010) Chemical characterization of municipal wastewater sludges produced by two-phase anaerobic digestion for biogas production. J Hazard Mater 175:740-746. https://doi.org/10. 1016/j.jhazmat.2009.10.071

Fry B (2006) Stable isotope ecology. Springer, New York

Gehring T, Klang J, Niedermayr A, Berzio S, Immenhauser A, Klocke M, Wichern M, Lübken M (2015) Determination of Methanogenic pathways through carbon isotope $(\delta 13 \mathrm{C})$ analysis for the two-stage anaerobic digestion of high-solids substrates. Environ Sci Technol 49:4705-4714. https://doi.org/10.1021/es505665z

Gelwicks JT, Risatti JB, Hayes JM (1994) Carbon isotope effects associated with Aceticlastic Methanogenesis. Appl Environ Microbiol 60: 467-472

Gleixner G, Bol R, Balesdent J (1999) Molecular insight into soil carbon turnover. Rapid Commun Mass Spectrom 13:1278-1283. https:// doi.org/10.1002/(SICI)1097-0231(19990715)13:13<1278::AIDRCM649>3.0.CO;2-N

Golkowska K, Greger M (2013) Anaerobic digestion of maize and cellulose under thermophilic and mesophilic conditions - a comparative study. Biomass Bioenergy 56:545-554. https://doi.org/10.1016/j. biombioe.2013.05.029

Haubert D, Birkhofer K, Fließbach A, Gehre M, Scheu S, Ruess L (2009) Trophic structure and major trophic links in conventional versus organic farming systems as indicated by carbon stable isotope ratios of fatty acids. Oikos 118:1579-1589. https://doi.org/10.1111/j.16000706.2009.17587.x

Herrmann C, Heiermann M, Idler C (2011) Effects of ensiling, silage additives and storage period on methane formation of biogas crops. Bioresour Technol 102:5153-5161. https://doi.org/10.1016/j. biortech.2011.01.012

Hobbie EA, Werner RA (2004) Intramolecular, compound-specific, and bulk carbon isotope patterns in $\mathrm{C} 3$ and $\mathrm{C} 4$ plants: a review and synthesis. New Phytol 161:371-385. https://doi.org/10.1111/j. 1469-8137.2004.00970.x

Junk G, Svec HJ (1958) The absolute abundance of the nitrogen isotopes in the atmosphere and compressed gas from various sources. Geochim Cosmochim Acta 14:234-243. https://doi.org/10.1016/ 0016-7037(58)90082-6

Krzycki JA, Kenealy WR, DeNiro MJ, Zeikus JG (1987) Stable carbon isotope fractionation by Methanosarcina barkeri during 
Methanogenesis from acetate, methanol, or carbon dioxide-hydrogen. Appl Environ Microbiol 53:2597-2599

Laukenmann S, Heuwinkel H, Keppler F (2009) Stabile Kohlenstoffisotope: Eine neue Lasermethode zur Prozessanalyse und Identifikation mikrobiologischer Reaktionen im Biogasprozess. In: Int Wissenschaftstagung Biogas Sci, Bayerische Landesanstalt für Landwirtschaft (LfL), Freising-Weihenstephan, Germany. 369-376

McDonald P, Henderson AR, Heron S (1991) The biochemistry of silage, 2nd edn. Chalcombe Publications, Marlow

Mösche M, Jördening HJ (1999) Comparison of different models of substrate and product inhibition in anaerobic digestion. Water Res 33: 2545-2554. https://doi.org/10.1016/S0043-1354(98)00490-4

Naik L, Gebreegziabher Z, Tumwesige V, Balana BB, Mwirigi J, Austin G (2014) Factors determining the stability and productivity of small scale anaerobic digesters. Biomass Bioenergy 70:51-57. https://doi. org/10.1016/j.biombioe.2014.01.055

Oude Elferink SJWH, Driehuis F (2000) Silage fermentation processes and their manipulation. In: FAO Electron Conf trop silage, food and agriculture organization (FAO), Rome, Italy 17-30

Pap B, Györkei Á, Boboescu IZ, Nagy IK, Bíró T, Kondorosi É, Marótibc G (2015) Temperature-dependent transformation of biogasproducing microbial communities points to the increased importance of hydrogenotrophic methanogenesis under thermophilic operation. Bioresour Technol 177:375-380. https://doi.org/10.1016/j. biortech.2014.11.021

Penger J, Conrad R, Blaser M (2014) Stable carbon isotope fractionation of six strongly fractionating microorganisms is not affected by growth temperature under laboratory conditions. Geochim Cosmochim Acta 140:95-105. https://doi.org/10.1016/j.gca.2014. 05.015

Qi H, Coplen TB, Geilmann H, Brand WA, Böhlke JK (2003) Two new organic reference materials for $\mathrm{d}^{13} \mathrm{C}$ and $\mathrm{d}^{15} \mathrm{~N}$ measurements and a new value for the $\mathrm{d}^{13} \mathrm{C}$ of NBS 22 oil. Rapid Commun Mass Spectrom 17:2483-2487. https://doi.org/10.1002/rcm.1219

Ruile S, Schmitz S, Mönch-Tegeder M, Oechsner H (2015) Degradation efficiency of agricultural biogas plants - a full-scale study. Bioresour Technol 178:341-349. https://doi.org/10.1016/j.biortech.2014.10. 053

Sakar S, Yetilmezsoy K, Kocak E (2009) Anaerobic digestion technology in poultry and livestock waste treatment-a literature review. Waste Manag Res 27:3-18. 10.1177/0734242X07079060
Schwertl M, Auerswald K, Schäufele R, Schnyder H (2005) Carbon and nitrogen stable isotope composition of cattle hair: ecological fingerprints of production systems? Agric Ecosyst Environ 109:153-165. https://doi.org/10.1016/j.agee.2005.01.015

Shearer GB, Kohl DH, Commoner B (1974) The precision of determinations of the natural abundance of nitrogen-15 in soils, fertilizers, and shelf chemicals. Soil Sci 118:308-314

Smith BN, Epstein S (1971) Two categories of ${ }^{13} \mathrm{C} /{ }^{12} \mathrm{C}$ ratios for higher plants. Plant Physiol 47:380-384. https://doi.org/10.1104/pp.47.3. 380

VDI (2006) VDI 4630 fermentation of organic materials - characterisation of the substrate, Sampling, Collection of Material Data, Fermentation Tests, Beuth Verlag, Berlin, Germany

VDLUFA (1997) Method book III - the chemical analysis of feedstuffs. 3rd ed.VDLUFA Verlag, Darmstadt, Germany

Vervaeren H, Hostyn K, Ghekiere G, Willems B (2010) Biological ensilage additives as pretreatment for maize to increase the biogas production. Renew Energy 35:2089-2093. https://doi.org/10.1016/j. renene.2010.02.010

Voß E, Weichgreber D, Rosenwinkel KH (2009) FOS/TAC - Deduction, Methods, Application and Significance. In: Int Wissenschaftskonferenz Biogas Sci, Bayerische Landesanstalt für Landwirtschaft (LfL), Freising-Weihenstephan, Germany

Wang Y, Zhang Y, Wang J, Meng L (2009) Effects of volatile fatty acid concentrations on methane yield and methanogenic bacteria. Biomass Bioenergy 33:848-853. https://doi.org/10.1016/j. biombioe.2009.01.007

Weiland P (2010) Biogas production: current state and perspectives. Appl Microbiol Biotechnol 85:849-860. https://doi.org/10.1007/s00253009-2246-7

Werth M, Kuzyakov Y (2010) ${ }^{13} \mathrm{C}$ fractionation at the root-microorganisms-soil interface: a review and outlook for partitioning studies. Soil Biol Biochem 42:1372-1384. https://doi.org/10.1016/j.soilbio. 2010.04.009

Zhu B, Cheng W (2011) ${ }^{13} \mathrm{C}$ isotope fractionation during rhizosphere respiration of $\mathrm{C}_{3}$ and $\mathrm{C}_{4}$ plants. Plant Soil 342:277-287. https:// doi.org/10.1007/s11104-010-0691-9

Publisher's note Springer Nature remains neutral with regard to jurisdictional claims in published maps and institutional affiliations. 